\title{
Consuming the Frontier Illusion: The Construction of Suburban Masculinity in Richard Yates's Revolutionary Road
}

\author{
Michael P. Moreno
}

While the American Cold War policies of the 1950s were being spirited abroad in the form of a socio-political impasse between the United States and the Soviet Union, ${ }^{1}$ domestic ideologies of paranoia, propaganda, surveillance-as well as the widespread infringement of civil liberties - produced what Alan Nadel calls a "national narrative" of containment in all social, economic, and spatial facets of the country (17). Such narratives, formed via political and cultural proclamations and societal expectations, would guarantee that American superiority was maintained in the popular imagination and that the security and dominance of the nation's economic interests and technological ambitions would remain unfettered. Richard Yates's widely acclaimed Revolutionary Road produces a crystalline snapshot of this new Cold War national order, depicting the GI-turned-suburbanite and his awkward negotiation in the mid-1950s social terrain. ${ }^{2}$ Yates's image of the postwar nation is one in which a new enemy (the Communists) fuels the paranoia and passion for American conformity and technological advancement. In this new campaign by the cold warriors, the societal attributes of compliance and progress would be battled domestically in the new suburban trenches.

Revolutionary Road denotes a moment in American society when the United States was re-designing itself into a "new and improved" culture based upon material consumption of leisure products and lifestyle amenities. Accordingly, many postwar Americans quickly assumed this new collective identity while unconsciously

Michael P. Moreno is a Ph.D. candidate in English at the University of California-Riverside. His areas of interest include urban and suburban studies, American literature, spatial theory, and architecture. 
retaining the mantle of freedom and independence that was quintessential to the republic's nineteenth-century frontier image of itself, for the suburbs' historical link with the past paved the way for an ideal sense of domestication for the generation to come. Demonstrating this linear connection, Arelene Skolnick asserts that " $[t]$ he vision of a perfected family life in harmony with nature linked the postwar suburbs to the Victorian past as well as to the communes of the counterculture" (51). Significantly, this paradox of wanting community and security while coveting individuality and unrestrained mobility continues to mark the United States' psychological and spatial anatomy well into the twenty-first century. As political borders between streets, neighborhoods, cities, and nations slowly dissolve into pockets of economic and cultural crossroads, the American post-Cold War suburb resolutely sustains the secured frontier illusion of communal individualism within a more contained and militarized design of high-tech domiciles and gated communities.

Revolutionary Road typifies this displacement experienced in the 1950s between the waning era of manual industry and the emerging computer age. And yet, Yates's novel demonstrates this transformation firmly reifies, rather than revolutionizes, gender roles in the domestic sphere and, in the process, re-manufactures the suburban male from the "GI Joe" image of masculinity to an emasculated bodyan anonymous, gray-flanneled consumer. In so doing, Yates's novel helps to articulate an emergent literary voice that comes not from the urban or rural parcels of the United States but the suburbs, the genesis of the modern consumer identity and the landscape of imminent death for the American male.

This article will underscore how the political and economic discourses of Cold War America transformed the identity of the (predominantly Anglo-) American male by manufacturing and containing his identity within the consumptive topography of suburbia. ${ }^{3}$ Moreover, these underlining effects of Cold War culture instigated a national crisis that has not been addressed until recently via the formation of "masculine studies" in the academic circles or the pro-male marches and massgatherings in the socio-political spheres. Torn between the new world order of the consumption, leisure, and family-centric lifestyles of the suburbs and the desire for a masculinity fostered by frontier idealism and war heroism, the white male suburbanite experienced a growing sense of what I call "white plight." This term refers to the angst and crisis the white male envisions from his inability to reconsign himself to his position of power and recognize the privileged world he has inherited through a very controlled history of discrimination and supremacy - albeit, a world which is essentially prefabricated for him.

The Cold War era suburb, a project whose manifestation began to breech the rural rather than urban frontiers in an effort to curtail the housing crisis of the postwar United States, was the most prominent domestic site of American proliferation and voluntary sequestration. Accordingly, demobilized GI Joes from a wardriven economy abroad were entering into a postwar domestic economy that transformed the olive-drab, gun-toting war hero into a gray flanneled, paper-pushing cold warrior whose new superior officers were no longer the John Wayne-esque figures in the popular imagination, but rather faceless CEOs of the rising service corporations of mass production. "[T] 
America's democratic traditions continued to influence the people's expectations [of a postwar culture], despite the increasing routinization of everyday life and the loss of personal freedom to which it had led" (Corber 24). This domestic containment and control over the populace, it was believed by those in power, would ensure a harmonious and duty-bound society devoted to securing American interests both here and abroad.

Although the spatial-political terrain of the suburbs conferred to many young men after WW II was intended to reintegrate them into a new American society, this act of seeming benevolence on the part of a paternalistic government actually rendered these men powerless and delionized. Just as the war hero was trained to follow orders and respect his chain of command in the field of battle, so too would he be expected to provide the energy that kept the wheels of domestic industry turning. In turn, the cold warrior "would be judged not on his personal dominance but on his sense of duty, his voluntary service to an organization made up of equally anonymous men" living in one of the many thousands of governmentally subsidized tract housing developments sprouting all around the country (Faludi 19). The American suburb, as such, became a commodified site wherein the American veteran would prove his unwavering commitment to the mutable causes of the United States not by proving his masculinity through the prowess of combat, but by becoming a consumer of postwar domestic accessories and their corresponding ideologies.

Whereas the cold warrior/organization man became a veritable foot soldier in the service industrial economy, the suburb emerged as the new illusory frontier of consumption, a stage upon which to showcase American ingenuity and decadence for the rest of the world, one that was slowly emerging from the rubble and ashes of an artillery Holocaust. As such, Cold War economic reforms of production and consumption confined the traditional frontier spirit of the white American male to the domestic sphere. Henceforth, according to Robert Corber, organization men "were expected to define themselves through their identities as consumers - an expectation hitherto confined to women - and to take an active role in childrearing" (5-6), as well as home maintenance and, more importantly, to abandon their claims to any form of independence that ran contrary to the American ideal of Cold War conformity and consumerism. Romanticized for its aesthetic qualities of privacy and safety, disparaged for its dystopic homogeneity and pseudo-frontierism, the Cold War suburb, an immediate byproduct of the domestic containment culture, paradoxically generated an impression of freedom and mobility while, in practice, it became the primary site of contention and emasculation for many white males who inhabited its engineered terrain.

In comprehending the transmutation the American male experienced during the Cold War era, it is important to examine the design of a "new and improved" masculine identity, which manifested itself in what William $\mathrm{H}$. Whyte calls the organization man. Unlike the detached, male entrepreneur of the early American metropolis or frontier plane, the organization man was to become a domesticated $\operatorname{cog}$ in the corporate wheel who dwelled in the suburbs and consumed products from the burgeoning mass market economy. In this new economic age of labor, the 
male worker was no longer able to "realize himself in his work, for work is now a set of skills sold to another, rather than something mixed with his own property" or craftsmanship-labor characteristics which denoted the male worker prior to the war's end (Mills 14). Thus, what emerged from this socio-economic revolution were unique dichotomies in which the white male was in continual renegotiation between public and private, urban and suburban, self-reliant and familial, productive and consumptive spheres of proliferation and containment.

The organization man arose out of the need to restructure the labor force in the postwar period, along the lines of the Fordist model of organizing production and consumption; that is, the model of working wages and labor organizations set forth at the dawn of the twentieth century. The Fordist model reconfigured the national economy and gave it the necessary boost to expand the domestic and global markets, thus transforming it fully from the nineteenth-century model of industrial capitalism to one designed to have a corporate/monopolistic center (Harvey 124125). ${ }^{4}$ In turn, this created a new identity for the American laborer in the form of the organization man, a twentieth-century paragon of cautiousness whose efficiency and corporate loyalty replaced the out-moded nineteenth-century entrepreneurial spirit of the thrifty, competitive, and self-disciplined laborer (Corber 32). Whereas the organization man is, according to Whyte, "keenly aware of how much more deeply beholden [he is] to [the] organization" (4), the nineteenth-century laborerwithin the paradigm of pioneering - was beholden to no one and lived freely on the open frontier, somewhere between the scintillating stars and rolling amber waves of grain in the American Promised Land. By the 1950s, organization men comprised the broad labor force for America's growing middle class and marked the social and economic landscape with their suburban sensibilities and gray flannel suits. ${ }^{5}$ Integral to their identities were their homes in the suburbs, where they "could display [their] success through the accumulation of consumer goods" (May 164) and ideally not have to answer to the company boss or respond to deadlines.

Although the organization man was not to be considered an emasculated drone, he was, nevertheless, often distraught by the loss of his identity and his manhood in wearing the suburban apron of consumerism and familialism. Yates's Revolutionary Road takes place in the midst of this Cold War culture and is set firmly within the 1955 western Connecticut suburban landscape of homogeneity, domesticity, and consumerism. Yates's protagonist, Frank Wheeler, is caught at the crossroads of his yearning to return to a more bachelor-like frontier world of masculinity, intellect, and adventure and his obligation to perform the blurred roles of organization man, suburban father, and compatible husband. ${ }^{6}$ The novel showcases the fall of the pre-packaged life of the suburban male by pitting Frank's identity crisis against his wife's frustration with disenfranchisement. The cold war that transpires within the Wheeler household is indicative of silenced domestic tensions manifesting themselves across postwar America.

As the portrait of suburban masculinity and cold warriorism, Frank is the very television-etched countenance reflected in Whyte's archetypal organization man: "neat and solid, a few days less than thirty years old, with closely cut black hair and the kind of unemphatic good looks that an advertising photographer might use to 
portray the discerning consumer of well-made but inexpensive merchandise" (12). And yet, even still, there is a kind of mobility about his appearance, one that "suggest[ed] wholly different personalities with each flickering change of expression" (12). Frank Wheeler, too, suffers from white plight, that inner struggle between conforming to the mores of the Cold War and escaping from them into an illusory wilderness of personalized possibilities.

Frank's small "flickering" of desire to be freed of obligations and roam the open landscape of a romanticized America is further agitated by the suburban parcels which Frank Wheeler and his fellow white middle-class suburbanites have colonized. The consumptive artifacts that now populate the area in which they live, the mass produced homes, the large chromed vehicles, the centerless strip malls, all appear to be out of sync with the patterns of history and the contours of the original countryside, thus creating an impression not of freedom or congruency, but rather containment and violation. A passerby traversing the literary spaces of Yates's suburban pocket

would see a landscape in which only a few very old, weathered houses seemed to belong; it made [the suburbanites'] own homes look as weightless and impermanent, as foolishly misplaced as a great many bright new toys that had been left outdoors overnight and rained on. Their automobiles didn't look right eitherunnecessarily wide and gleaming in the colors of candy and ice cream, seeming to wince at each splatter of mud, they crawled apologetically down the broken roads that led from all directions to the deep, level slab of Route Twelve. (5)

The Wheelers' lifestyle is that of the brave new suburban world, a world designed by the proliferation of consumer goods which envisioned a twentieth-century notion of a nineteenth-century utopic ideal. The grand developers of instant neighborhoods and streets who manufactured these prefabricated communities in the image of the organization man (Whyte 267) believed they were democratizing the daily life of the American citizenry by admitting some of its members into the American Dreamscape. ${ }^{7}$ As such, it was supposed to be a privilege to occupy the new domestic spaces of suburbia, for living in this sphere was the manifestation of the Cold War American Dream, it seemed.

Frank Wheeler, as "a gray flannel rebel and brilliant practitioner of . . . higher conformity" (Ehrenreich 31), sees his life slowly morphing into an Epsom Saltcured bathtub of comfort and predictability. Likewise, Frank's wife, April Wheeler, is caught within the web of performing as the organization man's wife. Their tasks revolved around the fulfillment of "domestic activities," according to Betty Friedman, which were comprised of "kissing their husbands goodbye in front of the picture window, depositing their station wagon full of children at school, and smiling as they ran the new electric waxer over the spotless floor" (14). Relegated to child care, Tupperware parties, and other small scale endeavors that promoted Euro-American cultural awareness within the community, educated, white, middleclass women, like April, were removed from the larger sectors of the work force after the war and discouraged, even prevented, from pursuing career opportunities in light of their new role as suburban homemaker. Elaine Tyler May contends that 
"[t]he ideological connections among early marriage, sexual containment, and traditional gender roles merged in the context of the cold war. Experts called upon women to embrace domesticity in service to the nation, in the same spirit that they had come to the country's aid by taking wartime jobs" (89). Appropriately, Revolutionary Road commences with residents attending the opening night of a play in which the Laurel Players, the recently organized theater group initiated by April and several other would-be Thespian suburbanites, are performing. The romantic pining for another world outside of the one made possible by the Organization is certainly not lost on April, who longs "to go out and do something that's absolutely crazy, and marvelous," something that will make her "sparkle all over," as her stage character elucidates on the night of the performance (8).

The play itself is an utter disaster and establishes a pace for the downward spiral of events in which the Wheelers' lives begin to break apart into sharp dissatisfaction through Frank's loss of his masculinity, April's sense of personal deficiency and disempowerment as a woman, the impasse of their marriage, and the stifling containment both of them feel living in the suburbs. Nevertheless, Frank Wheeler resists the notion that he and his wife are authentic suburbanites. ${ }^{8}$ It is imperative to Frank, as a gray flannel rebel, that he somehow transcend the stereotype of the organization man; although he must live within the spaces of suburbia, "the important thing was to keep from being contaminated. The important thing, always, was to remember who [he] is" (20). However, who Frank is and who he thinks he is do not necessarily coincide during his personal odyssey to recuperate his masculinity.

When Frank incessantly complains throughout the novel about the alienating role of suburban fathers, the disgust and anger he articulates stems from the fear of being contaminated by them, rather than from his anxiety that he is indistinguishable from them. Although he outwardly maintains that he is not one of them, Frank truly is no different from " "all the men [who have been] emasculated" (129) by their status as a consumer and by their effete representation in Cold War magazine advertisements and television sitcoms. By donning the gray flannel suit and moving to the suburbs, the organization man inevitably loses his masculine identity as the war-hero "[b]ecause that is what happens; that is what's reflected in all [the] bleating about 'adjustment' and 'security' and 'togetherness' . . . you see it everywhere; all this television crap where every joke is built on the premise that daddy's an idiot and mother's always on to him" (129). In the years following the close of World War II, consumer spending dramatically increased, and a substantial portion of this spending came from men, such as Frank, as much as it came from women, such as April, thus furthering the male's transformation from the old image of the rugged, individualistic, self-reliant entrepreneur to the loyal, respectful, compatible organization man, "all qualities associated with femininity" (Corber 6).

Frank believes that by avoiding the traditional expectations of suburban life, he can escape the loss of his masculinity and succeed in foiling the yoke of organization man/suburbanite. Indeed, he is resilient in convincing others, as well as himself, that he does not "fit the role of dumb, insensitive suburban husband," and he accuses his wife April of "trying to hang that one on [him] ever since [they] 
moved out [to the suburbs]" (25). In Frank's world, the blame is easily transferable to other people, his wife in particular. However, his outward protests fail, as Yates portrays him not as an independent man who refuses to succumb to the containment of domesticity, but rather as a lazy, directionless drunk who cannot perform the simple duties around the house and has no control over the elements surrounding him.

This loss of his role and control is underscored in the lawnmowing disagreement in chapter three, whereby Frank and April's battle over the lawn becomes a symbol of Frank's campaign for his Cold War masculinity. Awakening from a late night solo-drinking binge, Frank rises at eleven o'clock on a Saturday morning to the sound of April mowing the lawn. Decked out in Frank's old clothing, April assumes the role of suburban lawn-keeper, which is traditionally a masculine duty; however, she does this more out of a feeling of disgust for her husband's laxity than out of a desire to compromise her husband's position in the family. Frank, of course, does not interpret her actions this way. As such, he has forfeited more than his function as the man of the house-however implicating and emasculating that title might be in the topography of suburbia. He has lost all semblance of his place and has thrusted his duties onto April who, out of her own frustration as a servile Cold War housewife, reluctantly performs in order to maintain a sense of stability in their lives.

Later in the scene, Frank retires to the bathroom and scrutinizes his hands, the symbol of a true laborer and an icon of masculine strength and power. Unlike his father's hands, which were sure and massive as if "something unique and splendid had lived within [them]" (37), his own are antithetically "[b]loated and pale ... as if all their bones had been painlessly removed. A command to clench them into fists would have sent him whimpering to his knees" (35). In a further attempt to recover his manhood, Frank convinces himself that after "he'd had some coffee" and had dressed himself properly, he would "go out and take the lawnmower away from [April], by force if necessary, in order to restore as much balance to the morning as possible. But he was still in his bathrobe, unshaven and fumbling at the knobs of the electric stove" (40). The attempt to assert himself and reclaim his position of power is simply another failure of the morning and their marriage, further convictions that his masculinity has been placed in greater jeopardy by the very design of suburban life. In essence, the suburban male is a role Frank does not want, yet, as the only form of masculinity offered to him, he cannot allow that role, however ridiculed and demeaning, to be usurped from him as well.

Later the same afternoon, Frank resumes work on digging out a pathway from the house to the road. Initially, the excessive endeavor "was turning into mindless, unrewarding work" (40). However, once the "puffing and dizziness" subsides, he begins to garner a sense of working the land like a true pioneer, a man of the earth, a laborer in the fields, for this "was a man's work" (45). Now he could "take pleasure in the sight of his own flexed thigh ... and of the heavily veined forearm that lay across [the shovel] and the dirty hand that hung there" (45). Accordingly, Frank sees such physical labor as akin to the work of real men who tamed the wild American frontier and conquered their enemies - whether they were Nazis or Commu- 
nists or simply the sloping grades of the suburban front yard. Decorated in his army pants and a ripped shirt, Frank's wartime image of himself as hero and fighter fuels his fantasy of a world to which he no longer can return. His nostalgic pining thus aptly correlates with Susan Faludi's assertion that the returned soldier seems destined to the organization and suburban identity, for the Cold War climate had assured the GI's place firmly within the socio-economic bosom of postwar America (19-20). The returned soldier's sense of duty and his training to deflect the ubiquitous enemy - which now lurked somewhere behind the Iron Curtain or within the secret files of the House Committee on Un-American Activities-could best be demonstrated by his obedient silence behind the drawn Brocade Curtain of the suburban picture window. As Faludi maintains:

The promise was that wartime masculinity, with its common mission, common enemy, and clear frontier, would continue in peacetime .... Within the context of the cold war, the Postwar man, too, seemed to share with his cohorts a common mission of prevailing in a struggle against Communism and the battlements of Europe, throughout Asia, at home, and even on the frontiers of outer space. (19)

Frank Wheeler's inability to see the part he plays in the domestic struggle to maintain American superiority at home and abroad, and to locate a space within the suburban system that expresses this masculinity, manifests itself in his frustration and rage and, ultimately, in his helplessness.

Frank's own disillusionment with organization life and the suburbs inspires April to devise a plan that will salvage not only Frank's manhood but their marriage as well. Concurring with his disgust and boredom with their middle-class lifestyle, April decides to sell everything and move to Paris, where she can support him and where the children can be made invisible by the care of a nanny. In Paris, Frank will "[have] a chance to find [himself]" (114), which will bring order to their chaotic household and rectify the error committed by the unexpected arrival of their first child that pushed them out into the suburbs six years earlier. For the Cold War couple, relocating to Paris would be symbolic of returning to a white Western center of culture and history, something the United States was passionate about protecting and containing from the Soviets after the war had ended.

However, the dream of living in the lap of European urban culture soon begins to unravel when Frank is offered a lucrative position with a substantial pay raise by the now-computerizing Organization and April, again, becomes unexpectedly pregnant. When April contemplates her options for terminating the pregnancy, Frank's self-righteous convictions resurface, and he admonishes her for not only acting criminally, but also threatening his masculinity as a father figure. Yates writes: "How much, he would ask her, would his prime of manhood be worth if it had to be made conditional on allowing her to commit a criminal mutilation of herself?" (217218). Because aborting his child could never be an option for Frank, he slowly slides from the ideal of living in Paris to the reality of bringing up a third child in the suburbs. The career elevation and the prospect of heralding in the age of computers become far more attractive than gambling on a life beyond the protective walls of America or violating the natural order of cycles, as he sees it. 
Thereafter, Frank and April are beyond issues of suburban contamination or happy home life; they become invisible to each other. Like the impasse between the United States and the Soviet Union, the Wheelers find themselves in a Cold War marriage, both challenging and containing the other while preserving and protecting the self. Allegorically, this cold war, which has been brewing in the house for quite some time now, progresses towards a climactic assault. While April insists that she "loathe[s] the sight of [Frank]" (290), he, in turn, confesses that he secretly wished she had aborted the child she is carrying. Their suburban home, a symbolic battlefield, has been bloodied and ravaged beyond recognition. The final chord of this marital cold war must be struck; the nuclear arsenal, which has been proliferating between Frank and April for the past several months, will finally be used to break the spell of containment and oppression.

Revolutionary Road ends with the haunting demise of April, whose self-induced abortion causes her to hemorrhage then bleed to death in the hospital, thus becoming the novel's Cold War casualty. The Wheeler household has disintegrated beneath a silent mushroom cloud of atomic conflict because Frank and April challenged the dominant discourse of the Cold War that dictated they remain safely behind the Brocade Curtain of suburban domesticity. For, as May would articulate it, they failed at being

[the ideal suburban couple who] were expected to build a home that would provide them with security and fulfillment, and shield them from the harsh realities of public life in the cold war era. [And yet, those] realities included not only the existence of atomic bombs, but massive impersonal organizations in which most men worked, institutional roadblocks to women with career ambitions, and hostility toward anyone whose private life did not conform to the heterosexual family pattern. $(183-184)$

The end of the Wheeler cold war does little to make Frank feel triumphant in all his past endeavors. While he returns to the city to take up a new life, his children are placed in the care of his older brother and his wife. Frank, at last, attains that independence he has so longed for, although it has been achieved at a high price. Forced out of his suburban Eden, he is alone now and has evolved into a man quite different from the bachelor who was living in Greenwich Village during his postcollege days: "He had a new way of laughing: a soft simpering giggle. You couldn't picture him really laughing, or really crying, or really sweating or eating or getting drunk or getting excited - or even standing up for himself.' (330). Although his white masculinity is reinstated by the mobility he can enjoy moving through the urban topography, in losing April and his children this masculinity has lost all resilience and serves to mutate and weaken Frank rather than empower him as it once did. By the end of the novel, Frank has become somewhat of a ghostly character fading in and out of his gray flannel suit, unable to fill the vacancy left by his family's disintegration.

Although Frank Wheeler feels anonymous in his world, Revolutionary Road empowers him by his textual visibility. In turn, April is made visible only by the shadow she casts in her husband's illuminated presence. Frank's real conflict, 
then, is not just his emasculation by the postwar system; rather, the conflict is rooted in his deprivation of the keys to the frontier, the promise of roaming the idealized geography of freedom and independence, the quintessential medal for which he fought in the war and which the Cold War culture denied him. While he unconsciously enjoys the security the postwar era provides, he longs to be the frontiersman, to be independent and ride the rails of America through a sanitized version of "the hobo jungles along the way" (18). This oscillation between pioneer spirit and suburbanite comfort marks the center of Frank's identity crisis and underscores the nature of his white plight.

What makes Richard Yates's Revolutionary Road portentous four decades later is how this novel reveals the origins of the male consumer identity and the disappearance of the frontier/war hero by the onset of the Cold War-all the while illustrating the crisis of contemporary tensions of masculinity. Despite the fabricated images of Hollywood's masculine ideal that men in the United States are offered for consumption-icons such as Stallone's Rocky/Rambo of the 1970s and ' 80 s, the one-liner Schwarzeneggers, ambitious corporate raiders, superhero film adaptations of the 1980s and ' 90 s, and the racially ambiguous Vin Diesel of the new millennium - there is no tangible alternative that defines masculinity outside of suburban consumer identity.

Since the start of the Cold War, masculinity has abided in the nostalgic landscape of the prewar past. It has evolved into an ornament that is "[c]onstructed around celebrity and image, glamour and entertainment, marketing and consumerism[;] it is a ceremonial gateway to nowhere" (Faludi 35). However, multiple attempts in the last several years to reverse the symbolic death of the American male, endeavors such as Robert Bly's masculinity camping trips, the Million Man March, or the Promise Keepers, have engendered new methods for resurrecting old forms of paternalism and the subjugation of women that seek to reaffirm the male's role of power and dominance, rather than address viable alternatives for a new post-Cold War masculinity.

Accordingly, Revolutionary Road serves as more than a historical marker of masculine dissolution in the societal ledger of the Cold War; it functions as a reminder that in America's suburbia masculinity has yet to be recovered or redefined in terms beyond the glamorizing or fetishizing tropes of man-as-commodity in the terrain of mass consumption. Even now, as the United States participates in war in the Middle East, the American male is offered only two forms of masculine identity: the resurrected GI overseas or the patriotic consumer living in the suburbs. Likewise, the suburbs, which continue to proliferate at alarming rates throughout the country, maintain their iconic representation as commodified sites for the male consumer. As such, the social, political, economic, and spatial systems the Cold War generated underscore Frank Wheeler's masculine death by manufacturing and bartering his (and every American male's) identity in the contemporary global market and allowing this symbolic demise to reproduce itself with each new decade and each new housing development that unfurls the suburbs across what little remains of America's open frontier. 


\section{Notes}

The author wishes to thank Prof. Steven Axelrod of the University of California-Riverside for his input and advice in working with this subject matter.

${ }^{1}$ See the "kitchen debate" between Khrushchev and Nixon in 1959 (May 16-20).

${ }^{2}$ Considered to be Yates's finest literary achievement, Revolutionary Road was nominated in 1961 for the National Book Award and has been received by critics quite favorably over the last four decades. Richard Ford suggests that Yates's book has been so successful in literary circles because readers continue to "marvel at its consummate writerliness, its almost simple durability as a purely made thing of words that defeats all attempts at classification" (xvi).

${ }^{3}$ Minorities and those not resembling "wholesome" American families were denied access to suburbia by restrictive covenants placed on developments or civic "red lining," which zoned areas "unworthy" of financial investment. Such city tactics and federal policies shamelessly discriminated against non-whites by containing them within urban public housing. In short, "American housing policy was not only devoid of social objectives, but instead helped establish the basis for social inequalities" particularly during the Cold War era (Jackson 230). For an in-depth explication of the discriminatory practices behind suburban proliferation, see Jackson; Lipsitz.

${ }^{4}$ The idea of Fordism has its origins in Henry Ford's 1914 installations of the fivedollars in an eight hour day wage earning system that befitted "workers manning the automated car assembly line he had established the year before at Dearborn, Michigan" (Harvey 125). This postwar boom from 1945 until the oil crisis and recession of 1973 "was built upon a certain set of labour control practices, technological mixes, consumption habits, and configurations of political-economic power" (Harvey 124), all of which served to strengthen and reconfigure the manner in which the American laborer worked for and conceived his/her position in the American economic super-structure. For a detailed account of Fordism, its history and methodology, see Harvey 125-140.

${ }^{5}$ This shift in labor from the machinist-skilled worker to the corporate/service industry-based employee was the heart of Cold War labor identity, yet this shift also created unemployment pockets which required many American workers to learn new skills in order to adapt: "The evolution of electronics was a trade-off for the American people. Computers brought about a rapid rise in productivity through the automation of numerous industries. But in doing so they stimulated technological unemployment: fewer workers were needed to accomplish the same amount of work. Computerized technology caused a decline in the demand for machinists; from 1950 to 1970 their numbers dropped from 535,000 to 390,000 " (Norton et al. 884).

${ }^{6}$ It is worth illustrating that there was, in fact, a route that stretched across the Connecticut colony (during the eighteenth century) from Plainfield in the east to Ridgebury in the southwest known as the "Revolutionary Road." According to Hans DePold, the road "was used by the American Continental Army to deploy troops in at least five military engagements [during the American Revolution], including the successful battle to drive the Red Coats out of Rhode Island. That victory made it possible for the French to land an army at Newport, RI, and to eventually join George Washington's Continental Army in the fight for American independence." Ford writes that "Yates himself . . admitted to an interviewer in 1974 that he "meant the title to suggest that the revolutionary road of $1776 \ldots$ our best and bravest revolutionary spirit [perhaps briefly embodied by the character of April Wheeler in the novel], had come to something very much like a dead end in the fifties"' (xix-xx).

${ }^{7}$ Concerned about the growing socio-economic tension of the years immediately fol- 
lowing World War II, many legislators and political leaders scrambled to pass bills that would firmly set the economy within a productive mode of operation and keep the masses content and contained. Socialism was on the rise and old guard politicians were pressured into balancing out federally funded reforms with a Capitalist spin. The housing crisis was on the top of the list of potential political backlashes against the government. As such, developers such as William Levitt, famous for his chain of "Levittowns" in the east, expressed his patriotic sentiments in 1948 by insisting that "[n]o man who owns a house and a lot can be a Communist; he has too much to do" (qtd. in Kelly 164). Kelly adds: "More important, he had too much at stake; responsible for the welfare of a family and committed to a 30-year mortgage on a house whose value was dependent on continuous maintenance, the homeowning veteran was unlikely to have the time or the inclination to social revolution" (164).

${ }^{8}$ Catherine Jurca points out that the term "city dweller," which suggests a residential space, is quite unique from the term "suburbanite," which "implies that where you live has something to do with who you are-it purports to be an identity category" (148).

\section{Works Cited}

Corber, Robert J. Homosexuality in Cold War America: Resistance and the Crisis of Masculinity. Durham, NC: Duke University Press, 2000.

DePold, Hans. Revolutionary Road in Connecticut. 13 Nov. $2001<\mathrm{http}$ ://www.ctssar.org/ revroad/index.htm>.

Ehrenreich, Barbara. The Hearts of Men: American Dreams and the Flight from Containment. Garden City, NY: Anchor Press, 1984.

Faludi, Susan. Stiffed: The Betrayal of the American Man. New York: William Morrow, 1999.

Ford, Richard. Introduction. Yates xv-xxvi.

Friedman, Betty. The Feminine Mystique. New York: Dell, 1963.

Harvey, David. The Condition of Postmodernity: An Enquiry into the Origins of Cultural Change. Cambridge, MA: Blackwell, 1990.

Jackson, Kenneth T. Crabgrass Frontier: The Suburbanization of the United States. New York: Oxford University Press, 1985.

Jurca, Catherine. White Diaspora: The Suburb and the Twentieth-Century American Novel. Princeton, NJ: Princeton University Press, 2001.

Kelly, Barbara M. Expanding the American Dream: Building and Rebuilding Levittown. Albany, NY: State University of New York Press, 1993.

Lipsitz, George. The Possessive Investment in Whiteness: How White People Profit from Identity Politics. Philadelphia, PA: Temple University Press, 1998.

May, Elaine Tyler. Homeward Bound: American Families in the Cold War Era. New York: Basic Books, 1988.

Mills, C. Wright. White Collar: The American Middle Classes. New York: Oxford University Press, 1951.

Nadel, Alan. Containment Culture: American Narratives, Postmodernism, and the Atomic Age. Durham, NC: Duke University Press, 1995.

Norton, Mary Beth, et al., eds. A People \& A Nation: A History of the United States. 3rd ed. Boston, MA: Houghton Mifflin, 1990.

Skolnick, Arelene. Embattled Paradise: The American Family in an Age of Uncertainty. New York: Basic Books, 1991.

Whyte, William H. Organization Man. New York: Simon \& Schuster, 1956.

Yates, Richard. Revolutionary Road. 1961. New York: Vintage Books, 2000. 